\title{
Does skill obsolescence increase the risk of employment loss?
}

Citation for published version (APA):

Allen, J. P., \& de Grip, A. (2012). Does skill obsolescence increase the risk of employment loss? Applied Economics, 44(25), 3237-3245. https://doi.org/10.1080/00036846.2011.570727

Document status and date:

Published: 01/01/2012

DOI:

10.1080/00036846.2011.570727

Document Version:

Publisher's PDF, also known as Version of record

Document license:

Taverne

Please check the document version of this publication:

- A submitted manuscript is the version of the article upon submission and before peer-review. There can be important differences between the submitted version and the official published version of record.

People interested in the research are advised to contact the author for the final version of the publication, or visit the DOI to the publisher's website.

- The final author version and the galley proof are versions of the publication after peer review.

- The final published version features the final layout of the paper including the volume, issue and page numbers.

Link to publication

\footnotetext{
General rights rights.

- You may freely distribute the URL identifying the publication in the public portal. please follow below link for the End User Agreement:

www.umlib.nl/taverne-license

Take down policy

If you believe that this document breaches copyright please contact us at:

repository@maastrichtuniversity.nl

providing details and we will investigate your claim.
}

Copyright and moral rights for the publications made accessible in the public portal are retained by the authors and/or other copyright owners and it is a condition of accessing publications that users recognise and abide by the legal requirements associated with these

- Users may download and print one copy of any publication from the public portal for the purpose of private study or research.

- You may not further distribute the material or use it for any profit-making activity or commercial gain

If the publication is distributed under the terms of Article $25 \mathrm{fa}$ of the Dutch Copyright Act, indicated by the "Taverne" license above, 


\section{Applied Economics}

\section{Does skill obsolescence increase the risk of employment loss?}

\section{Jim Allen \& Andries de Grip}

To cite this article: Jim Allen \& Andries de Grip (2012) Does skill obsolescence increase the risk of employment loss?, Applied Economics, 44:25, 3237-3245, DOI: 10.1080/00036846.2011.570727

To link to this article: https://doi.org/10.1080/00036846.2011.570727

册 Published online: 13 Jun 2011.

Submit your article to this journal

Џlll Article views: 694

Q View related articles $\sqsubset$

4 Citing articles: 9 View citing articles 


\title{
Does skill obsolescence increase the risk of employment loss?
}

\author{
Jim Allen ${ }^{\mathrm{a}}$ and Andries de Grip ${ }^{\mathrm{a}, \mathrm{b}, \mathrm{c}, *}$ \\ ${ }^{a}$ Research Centre for Education and the Labour Market (ROA), \\ Maastricht University, Maastricht, The Netherlands \\ ${ }^{\mathrm{b}}$ Institut zur Zukunft der Arbeit, Bonn, Germany \\ ${ }^{\mathrm{c}}$ Netspar, Tilburg, The Netherlands
}

In this article, we analyse whether technological change induces skill obsolescence and early labour market exit, and to what extent training participation and on the job learning reduce these risks. Using panel data on older workers, we find that workers report skill obsolescence more often when learning is a structural characteristic of the job. This perceived skill obsolescence is not related to a higher probability of losing employment. Instead, workers who experience skill obsolescence appear to learn more on the job and participate more often in training, which decreases the risk of losing employment. These results are consistent with the dynamic model of skill obsolescence and employment loss we develop in this article. Moreover, we find that when workers with long job tenures decrease their training participation, this is an early indicator of future job loss.

Keywords: human capital development; training; on-the-job learning; skill obsolescence; labour market participation

JEL Classification: J24; J26

\section{Introduction}

Older workers may face a decreasing productivity due to rapid changes in the world of work. The main motor of such change are the innovations based on information technology that are introduced all over the economy (Machin and van Reenen, 1998). These innovations change the skills required in many jobs (Dickerson and Green, 2004). Therefore, the skills workers already possess will tend to lose their relevance for the labour market, and their place will be taken by skills that were previously less important or not required at all (Welch and Ureta, 2002). This skill obsolescence will lead to increasing job insecurity over the life course, making it difficult to maintain an adequate level of labour market participation of older workers. Although pension schemes often encourage early retirement of workers whose productivity is waning, involuntary early retirement is widespread, particularly in Continental Europe (Dorn and Sousa-Poza, 2010)

In this article, we analyse whether information technology induces skill obsolescence and loss of work, and how this is related to workers' participation in training and learning on the job. We will compare two conceptual models on the relationships between technological change, training participation, on-the-job learning, skill obsolescence and the chance of losing employment. The first model is a static model, in which training participation is exogenous. This model reflects the conventional wisdom on skill obsolescence and the probability of employment loss

*Corresponding author. E-mail: a.degrip@maastrichtuniversity.nl 
(cf. OECD, 2001). The second model is a dynamic model in which skill obsolescence reinforces life-long learning, driven by technological change that takes place in the workplace. The latter model predicts that when workers experience skill obsolescence more or less continuously in their job, this may indicate a healthy dynamic situation in which technological change and the concomitant on-the-job learning create their own learning process.

Using panel data on older workers, we find that workers who experience skill obsolescence appear to learn more on the job and participate more often in training. Moreover, those who are employed in IT-intensive jobs are more likely to learn on the job. Remarkably, perceived skill obsolescence is not related to a higher probability of losing employment, whereas training participation decreases the risk of losing employment. These results are consistent with the dynamic model of skill obsolescence and employment loss we developed in this article. Furthermore, we find that when workers with long job tenures decrease their training participation, this is an early indicator of future job loss.

These findings contribute to the literature on the labour market withdrawal of older workers by emphasizing that skill obsolescence as well as investments in training and on-the-job learning are all more or less structural characteristics of jobs that are highly challenging and dynamic, and prevent that older workers withdraw from the labour market at an early age.

\section{Two Models of Skill Obsolescence}

In this section, we will develop two conceptual models that could explain skills obsolescence. First we will describe a static model, and then we will develop a more dynamic model that includes the learning of workers who face shifts in skill demanded in their jobs.

\section{Static model of skill obsolescence}

We start from the worker-job matching assumption that the performance of a given worker in a given job is a function of the overlap between the skills actually possessed by a worker and the skills needed to do the job (e.g. Jovanovic, 1979). Only the skills required in the job contribute to the worker's performance. In contrast, the remaining part of the worker's skills does not contribute to a worker's productivity in the job.
Over time, technological change can induce shifts in the skills needed to perform in a given job. If we assume for the moment that the worker's own skill level remains relatively static, this will change the worker-job match. In principle, the shift in the skills needed in the job can be in any direction with respect to the existing skills of the incumbent. This means that changes in the job tasks resulting from technological change could lead to either an improvement or deterioration in the match between actual and required skills. However, there are vastly more ways in which a change can lead to deterioration in the match than ways in which a change can lead to an improvement. Consequently, it is safe to assume that, in the aggregate, a change in the skills demanded will lead to a decrease in the volume of skills that are productively utilized.

Such a change has serious consequences for both the employee and the employer. From the point of view of the employee, underutilization of skills has strong unwanted effects on earnings (van Smoorenburg and van der Velden, 2000). By contrast, the major concern of employers will be about skill shortages, which lead directly to loss of potential output. In the ensuing discussion, we will concentrate on effects relating to skill shortages.

As a result of the deterioration in a worker's performance, the worker's hold on his or her job may become less secure. This particularly holds when wages are rigid (cf. Weiss and Garloff, 2009). Compared to the initial situation, the employer has a greater incentive to dismiss the current worker, and replace him or her by a worker with more appropriate skills (van Loo et al., 2001). Obviously, the worker's prospects of obtaining a similar or better position after dismissal will be bad. We would therefore expect that a higher skill gap increases the risk that the worker has to move to a worse job, or lose employment altogether. This risk is likely to be particularly great in countries such as the Netherlands where demand shifts away from unskilled labour tend to be absorbed more by a lower job security than through wage adjustments (Maurin and Postel-Vinay, 2005).

There are of course less drastic measures that can be used to reduce the skill gap following technological change. Where change is accompanied or followed by formal training, this can offset the negative effects of the change in required skills. If the acquisition of new skills is sufficient to at least offset the shift in skill requirements as a result of technological change, the worker's job security is not likely to be compromised, and may even improve. However, if training does not take place, or is insufficient to offset the shift in skill requirements, the worker may face a risk of losing his or her job. This risk could accumulate during a 


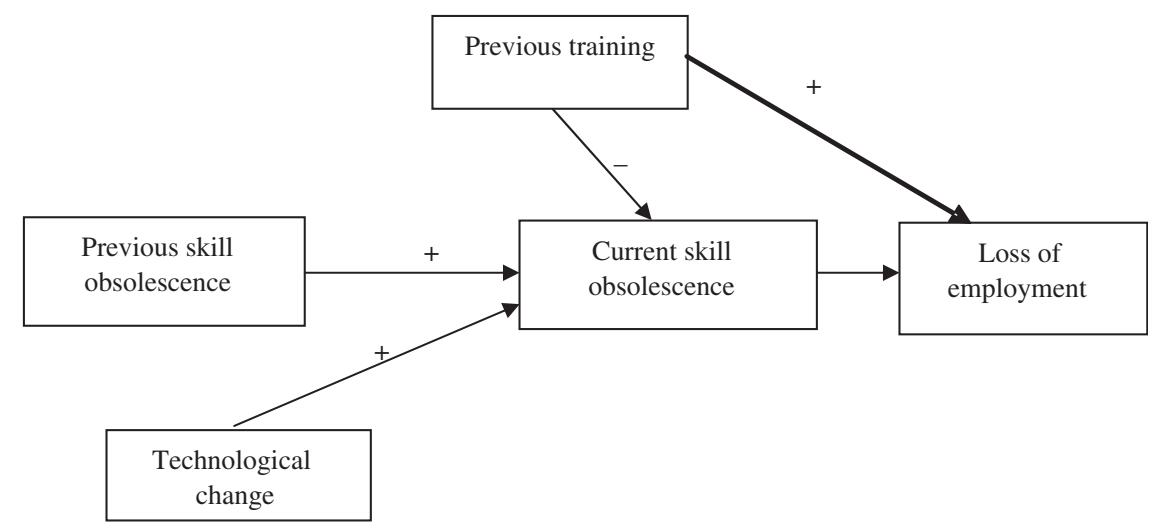

Fig. 1. Static model of skill obsolescence and employment loss

worker's career. Recalling that this conceptualization of the relation between technological change, skill obsolescence and training participation is based on the assumption that the worker's own skills remain relatively static except during periods of formal training, we call this the static model of skill obsolescence. Figure 1 summarizes the relations postulated by this model.

\section{Dynamic model of skill obsolescence}

When we drop the assumption that skill levels are static, a different model of the relation between technological change, skill obsolescence and labour market participation arises. Both the decision to train and the decision to organize work in such a way as to promote learning by doing may not be independent of technological change. On this point, it is crucial to note that changes that are expected to give rise to skill mismatches according to the static model could create their own learning situation: workers in organizations undergoing change are likely to be exposed to a wider variety of experiences from which they can learn new skills. In addition, both employers and workers may respond or anticipate the changes in technology by making greater investments in training (cf. Acemoglu, 1997). In other words, workers may more or less automatically learn new skills as the skill requirements arise. Jobs may be deliberately structured so as to provide learning opportunities (Eraut, 2000). This learning potential of the job (Rosen, 1972) is likely to be greatest in cases where the learning of new skills is deemed most necessary, i.e. in precisely those jobs where skill requirements are also changing rapidly. Whereas jobs characterized by repetitiveness, hierarchical control mechanisms and low levels of autonomy may stifle learning opportunities for workers, more complex jobs with shifting job contents offer ample opportunities for lifelong learning. This suggests that, rather than a situation in which the size of the skill gap after technological change is dependent on investments in training and on-the-job learning, these investments may in fact be dependent on the size of the initial skill gap and the new skill requirements resulting from technological change.

If formal and informal learning are indeed endogenous to technological change, this also changes the expected relation between obsolescence and labour market participation. If workers in changing organizations are continuously updating their skills to meet the changing requirements, they should be no more at risk of losing their jobs than workers in more stable organizations. This dynamic model is summarized in Fig. 2.

The figure shows that of the effects predicted by the static model, only the predicted positive relation between previous and current skill obsolescence remains in the dynamic model. However, even this superficial similarity might have a different interpretation in the two models. Whereas the static model views previous obsolescence as a burden that has to be overcome above and beyond the additional obsolescence induced by technological change, the dynamic model implies that, in some cases at least, skill obsolescence is a more or less structural characteristic of the job. Far from being a problem, in such jobs the perceived 'obsolescence' may be an indication of a healthy and dynamic situation with a high learning potential (cf. Bartel and Sicherman, 1993).

As 'old obsolescence' is eliminated by investments in training and/or on-the-job learning, 'new obsolescence' will pop up to take its place, which will stimulate the worker and/or the employer to invest in further training, and so on. If this is the case, this has some important implications. First, the development of human capital by participating in training and/or on-the-job learning will not reduce the skills gap. Second, the skill obsolescence perceived by the 


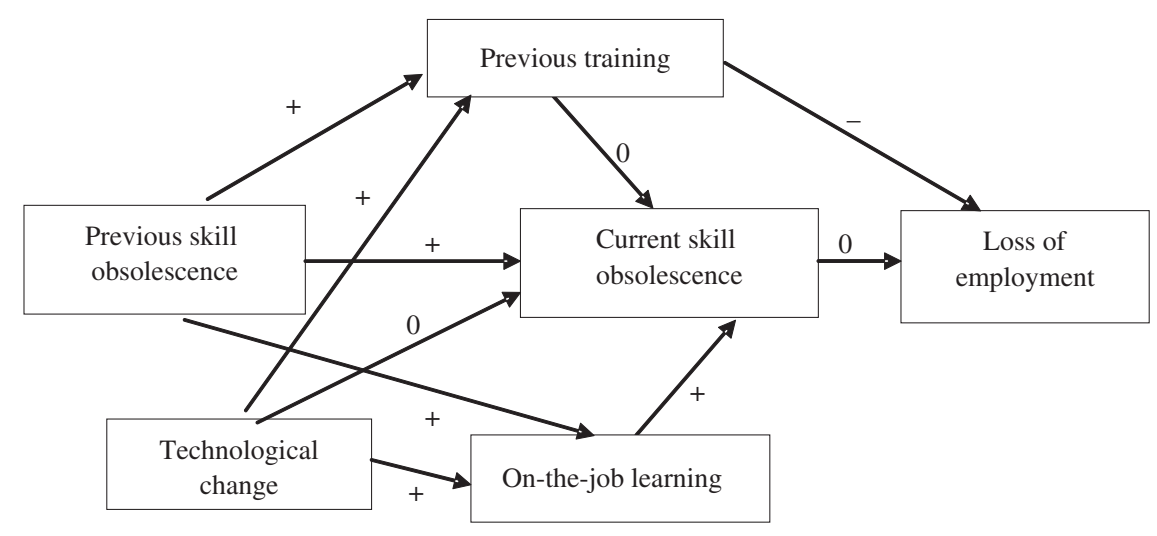

Fig. 2. Dynamic model of skill obsolescence and employment loss

worker will not increase a worker's risk of losing employment, as it merely indicates that a worker is employed in a dynamic job. Third, although the dynamic model predicts no indirect effect of training on the probability of employment loss, it does predict a direct negative effect. This is because training is regarded as an investment, which both employers and employees would like to recoup by extending the employment relationship.

\section{Data and Variables}

\section{Data}

For our analyses on the relationships between technological change, skill obsolescence and investments in human capital, we make use of data from the $O S A$ Labour Supply Panel. The OSA Labour Supply Panel consists of a representative biannual survey among a representative sample of the Dutch working age population. Due to the relatively high rate of panel attrition, which is compensated by adding new respondents in each new wave, we only use the panel character of the OSA data in a limited way. In order to increase the number of available cases in the analyses - which is particularly important because most of the dependent variables we consider are quite heavily skewed dummy variables - we treat each wave as an independent sample, and pool data over the three successive waves of 1994, 1996 and 1998. To the data for each of these waves, we add an indicator of skills obsolescence for the same respondents 2 years earlier, as well as an indicator of their labour market participation 2 years later. For example, the data for working respondents in the 1994 wave includes information on whether or not they suffered from skills obsolescence in 1992, and on whether or not they were still in paid employment in $1996 .{ }^{1}$

The data from the three waves are pooled, resulting in a pooled dataset containing 4683 usable cases, comprising a main body of variables in the reference year, with the relevant variables from the previous and subsequent waves appended. ${ }^{2}$ This is shown in Fig. $3 .^{3}$ To correct for the multiple occurrence of individual respondents, we use the 'Cluster' option in STATA to estimate robust SEs in our multivariate analyses.

In order to focus on the part of the workforce that is most at risk of losing its place in the labour market due to skill obsolescence, we include only respondents aged between 40 and 62 at the time of the survey. The reason for choosing 62 as an upper bound is that then all respondents are still below the official mandatory retirement age of 652 years later, when we again measure their labour market participation. $^{4}$

\footnotetext{
${ }^{1}$ As more recent waves of the OSA panel lack data on variables needed in our analysis, we have to restrict the analyses to the period 1992 to 2000 .

${ }^{2}$ Because we pool data from different years, some respondents are represented more than once in the data. The data contain a total of 2594 individual respondents, of which 1211 appear in only one of related survey years (e.g. 1992, 1994 and 1996), 677 appear twice and 706 in all 3 years.

${ }^{3}$ On average between $25 \%$ and $30 \%$ of respondents who participated in a given wave do not participate in the subsequent wave. Panel attrition shows little or no relation to key variables like skill obsolescence and on-the-job training. However, those who participated in training in a given period are somewhat less likely to drop out in the following wave. There is, however, no reason to expect that our results are affected by panel attrition, since this would require that both the dependent variables and at least some of the independent variables are related to the chance of participating in the following wave.

${ }^{4}$ For more information on the OSA Panel, see http://www.tilburguniversity.nl/osa/datasets.
} 


\begin{tabular}{|c|c|c|}
\hline Previous skill obsolescence & Main body of variables & $\begin{array}{c}\text { Subsequent labour market } \\
\text { participation }\end{array}$ \\
\hline 1992 & 1994 & 1996 \\
+ & + & + \\
\hline 1994 & 1996 & 1998 \\
+ & + & + \\
\hline 1996 & 1998 & 2000 \\
$=$ & $=$ & $=$ \\
\hline $1992+1994+1996$ & $1994+1996+1998$ & $1996+1998+2000$ \\
\hline
\end{tabular}

Fig. 3. The pooled dataset

\section{Variables}

In the analyses, skill obsolescence (both in the previous and current periods) is indicated by a respondent's answer to the following question: How do you consider the relation between your knowledge and skills and your job? Following the typology of skill obsolescence developed in de Grip and van Loo (2002) that distinguishes between technical and economic obsolescence of skills, we consider those who reported either an 'obsolescence of skills' or a 'skill shortage' in the period in question as workers who face skill obsolescence in their job. The reported 'obsolescence of skills' will particularly refer to technical obsolescence or depreciation of skills due to the wear of skills resulting from the natural ageing process, illness or injury, whereas skill shortages will include economic skill obsolescence due to external developments (such as changes in the technologies applied or changes in the organization) which lead to new skill demands for a worker's job. Loss of work is indicated by respondents who were in paid employment in the reference period but not 2 years later. Technological change is indicated by the IT-intensity of a worker's job measured by the percentage of employees in the respondent's occupational group who used a personal computer in their work (cf. Jorgenson, 2001). At first sight, one might wonder whether an aggregate measure of computer use adequately captures the kind of change we are interested in. We argue that an aggregate measure is in fact more appropriate than an individual measure, since a computer-intensive infrastructure forms part of the environment that allows - or forces - firms to innovate.

Building on Sieben et al. (2009), we include the variable on-the-job learning indicated by the time that the respondent expects to be needed for a comparably educated new employee to learn how to do the job. We need to emphasize here that the indicator does not refer to the actual induction time of the worker when he or she started in the job, but estimates the time a hypothetical replacement would need to learn the ropes. On the basis of the dynamic model, we assume that jobs that require a substantial amount of initial learning are knowledge or skill-intensive jobs, of which learning is more or less a structural characteristic. Of course, this assumption does not hold according to the static model, which if anything would predict that a lot of learning early on would reduce the need for later learning. This contrast makes this variable especially suitable for a comparison of the two models. Training participation (both previous and current) is indicated by (the natural logarithm of) the number of courses followed in the relevant 2-year period. In the case of previous training, this is the 2 years prior to the reference year. In the case of current training, it is the period of a year prior and a year subsequent to the reference period. ${ }^{5}$ As control variables in several analyses, we include tenure (both a linear and a quadratic term), occupational level, gender, age, cohort (survey year), firm size and economic sector. Table 1 shows the means and SDs of the interval level variables and the percentage distributions of the dummy variables used in the analysis.

\section{Estimation Results}

In the analyses that follow, we will test the applicability of the static and the dynamic model on the relations between the IT-intensity, training participation, on-the-job learning, skill obsolescence and loss of employment. First, we analyse the determinants of the skill obsolescence workers perceive in their current job. Second, we analyse the determinants of workers' probability of unemployment or labour

\footnotetext{
${ }^{5}$ We use two different indicators of training, which play two different roles in our analyses. Training in the previous period is used as a predictor of current skill obsolescence and the chance of losing one's work. Training in the current period is used as a dependent variable, with among other things, the percentage of computer use, the initial training time needed in the job and previous skill obsolescence as predictors. The fact that these two variables overlap partly does not present a problem, because they never appear together in any analyses.
} 
Table 1. Descriptive statistics of variables used in the analyses

\begin{tabular}{|c|c|c|c|}
\hline Variable & Percent & Mean & $\mathrm{SD}$ \\
\hline Skill obsolescence & 4.4 & - & - \\
\hline Loss of work & 6.8 & - & - \\
\hline IT-intensity ( $\%$ in occupational group) & - & 57.63 & 31.42 \\
\hline Previous training participation (number of courses) & - & 0.41 & 0.85 \\
\hline Current training participation (number of courses) & - & 0.43 & 0.90 \\
\hline On-the-job learning & - & 6.42 & 2.27 \\
\hline Previous skill obsolescence & 5.6 & - & - \\
\hline Tenure (years) & - & 14.27 & 10.09 \\
\hline \multicolumn{4}{|l|}{ Occupational level } \\
\hline Low & 35.7 & - & - \\
\hline Intermediate & 32.9 & - & \\
\hline High & 31.4 & - & - \\
\hline Gender (female) & 37.4 & - & - \\
\hline Age & - & 48.07 & 5.49 \\
\hline Cohort 1994 & 30.5 & - & - \\
\hline Cohort 1996 & 32.1 & & \\
\hline Cohort 1998 & 37.4 & - & - \\
\hline \multicolumn{4}{|l|}{ Firm size } \\
\hline$<10$ employees & 19.6 & - & - \\
\hline 10-99 employees & 39.0 & & \\
\hline$\geq 100$ employees & 41.4 & - & - \\
\hline \multicolumn{4}{|l|}{ Economic sector } \\
\hline Agriculture, forestry and fisheries & 2.9 & - & - \\
\hline Manufacturing and mining & 20.5 & - & - \\
\hline Business services & 31.6 & - & - \\
\hline Public services & 45.0 & - & - \\
\hline
\end{tabular}

Source: OSA Labour Supply Panel, 1992 to 2000.

market withdrawal in the subsequent period. As the results of these analyses support the dynamic model, we further test two other predictions of this model, namely that the IT-intensity and previous skill obsolescence are related to on-the-job learning as well as a worker's training participation.

\section{Current skill obsolescence}

In the first analysis, we attempt to explain skill obsolescence in the current period. According to the static model, perceived skill obsolescence will be positively related to both previous skill obsolescence and IT-intensity, and negatively related to training participation. The dynamic model also predicts a positive effect of previous obsolescence - albeit for a different reason - but predicts no significant effect of either IT-intensity or training participation. This model does predict a positive effect of the amount of on-the-job learning on perceived skill obsolescence. The results of the analysis of the skill obsolescence workers perceive in their job are presented in Table 2.

The estimation results provide strong support for the dynamic model, and little or no support for the static model. The only result that is consistent with the static model - that previous skill obsolescence is a strong predictor of current skill obsolescence - is also predicted by the dynamic model. However, contrary to the predictions of the static model but consistent with those of the dynamic model, IT-intensity and training participation have no effect, while on-the-job learning has a positive effect on current skill obsolescence.

\section{Loss of work}

Having established that the pattern of determinants of skill obsolescence is more consistent with the dynamic than with the static model, we now turn to the effects of skill obsolescence on the risk of losing employment in the subsequent period. The static model predicts that skill obsolescence will increase this risk substantially, as the loss of productivity related to obsolescence makes the worker's grip on employment increasingly tenuous. By contrast, the dynamic model predicts no such effect; because both obsolescence and learning are regarded as more or less structural characteristics of jobs, workers who experience obsolescence will not be more likely to lose their job than those who do not. Also in contrast to the static model is the predicted effect of training participation. According to the static model, any 
Table 2. Logit estimation of skill obsolescence in the current job

\begin{tabular}{|c|c|c|}
\hline & $B$ & Robust SE \\
\hline Constant & $-3.117^{* *}$ & 0.836 \\
\hline IT-intensity & 0.003 & 0.003 \\
\hline Previous training participation & 0.025 & 0.034 \\
\hline On-the-job learning & $0.113^{* *}$ & 0.043 \\
\hline Previous skill obsolescence & $1.478 * *$ & 0.225 \\
\hline Tenure & 0.017 & 0.026 \\
\hline Tenure-squared/100 & -0.073 & 0.077 \\
\hline \multicolumn{3}{|c|}{ Occupational level (reference, intermediate level) } \\
\hline Low level & $-0.473 *$ & 0.231 \\
\hline High level & -0.177 & 0.174 \\
\hline Gender (female) & -0.064 & 0.185 \\
\hline \multicolumn{3}{|l|}{ Cohort (reference, 1996) } \\
\hline 1994 & -0.107 & 0.172 \\
\hline 1998 & $-0.646^{* *}$ & 0.187 \\
\hline Age & -0.008 & 0.015 \\
\hline \multicolumn{3}{|c|}{ Firm size (reference, category 10-99 employees) } \\
\hline$<10$ employees & -0.129 & 0.223 \\
\hline$\geq 100$ employees & -0.149 & 0.166 \\
\hline \multicolumn{3}{|c|}{ Economic sector (reference, manufacturing and mining) } \\
\hline $\begin{array}{l}\text { Agriculture, forestry } \\
\text { and fisheries }\end{array}$ & -0.250 & 0.531 \\
\hline Business services & 0.163 & 0.209 \\
\hline Public services & -0.256 & 0.215 \\
\hline
\end{tabular}

Notes: $N=4528$; Pseudo $R^{2}=0.056$.

$* p<0.05, * * p<0.01$.

effect of training on the risk of losing one's work will be indirect, through its supposed effect on skill obsolescence. By contrast, the dynamic model predicts a direct negative effect of training participation on losing one's job. This is because training is regarded as an investment, which both employers and employees would like to recoup by extending the employment relationship. Table 3 shows the results of this analysis.

Again, the results are more in line with the dynamic model than with the static model. Skill obsolescence has no effect on the risk of losing one's work. On the other hand, training participation does significantly reduce the risk of losing employment. Even though training does not have a net effect on perceived skill obsolescence, it does reduce the risk of losing employment, as expected in the dynamic model.

An interesting effect not directly predicted by either model is that of tenure. Tenure shows a negative linear effect and positive quadratic effect on the risk of losing employment. The negative linear effect suggests that, up to a point, additional experience in a job adds to security in that job. This could be related to progressive acquisition of human capital by learning on the job, although it could also indicate that the legal claim to one's position gets stronger over time. However, as time progresses, the effect of tenure on the probability of job loss becomes smaller, eventually leading to a
Table 3. Logit estimation of loss of work

\begin{tabular}{|c|c|c|}
\hline & $B$ & Robust SE \\
\hline Constant & $-11.670^{* *}$ & 0.953 \\
\hline IT intensity & 0.001 & 0.003 \\
\hline Previous training participation & $-0.109 *$ & 0.043 \\
\hline On-the-job learning & -0.056 & 0.036 \\
\hline Skillobsolescence & 0.184 & 0.354 \\
\hline Tenure & $-0.061 * *$ & 0.024 \\
\hline Tenure-squared/100 & $0.166^{* *}$ & 0.062 \\
\hline \multicolumn{3}{|c|}{ Occupational level (reference, intermediate level) } \\
\hline Low level & -0.092 & 0.201 \\
\hline High level & -0.235 & 0.202 \\
\hline Gender (female) & $0.579 * *$ & 0.177 \\
\hline \multicolumn{3}{|l|}{ Cohort (reference, 1996) } \\
\hline 1994 & $0.356^{*}$ & 0.174 \\
\hline 1998 & 0.014 & 0.195 \\
\hline Age & $0.182 * *$ & 0.017 \\
\hline \multicolumn{3}{|c|}{ Firm size (reference, category 10-99 employees) } \\
\hline$<10$ employees & -0.195 & 0.221 \\
\hline$\geq 100$ employees & 0.118 & 0.175 \\
\hline \multicolumn{3}{|c|}{ Economic sector (reference, manufacturing and mining) } \\
\hline $\begin{array}{l}\text { Agriculture, forestry } \\
\text { and fisheries }\end{array}$ & -0.188 & 0.477 \\
\hline Business services & 0.145 & 0.209 \\
\hline Public services & -0.339 & 0.227 \\
\hline
\end{tabular}

Notes: $N=3.236$; Pseudo $R^{2}=0.155$.

$* p<0.05, * * p<0.01$.

higher risk of job loss for those who are more than 18 years employed in the same job. This suggests that a concentration of experience in a particular job eventually leads to stagnation and lower employability in the longer term. Since we have controlled for age which has the expected positive effect on the chance of losing employment related to (early) retirement - this result cannot be attributed to life-cycle effects. Remarkably, women also have a higher chance of losing employment than men.

\section{On-the-job learning}

As the results so far strongly support the dynamic model, we will proceed by testing a number of more specific predictions of this model. The dynamic model predicts that technological change as well as the perception of skill obsolescence will contribute positively to on-the-job learning. The estimation results presented in Table 4 confirm these expectations: both the IT-intensity and previous skill obsolescence positively affect on-the-job learning.

\section{Training participation}

A final prediction of the dynamic model is that training participation is also endogenously influenced by both previous obsolescence and IT-intensity. 
Table 4. Regression analysis of on-the-job learning

\begin{tabular}{|c|c|c|}
\hline & $B$ & Robust SE \\
\hline Constant & $5.935 * *$ & 0.433 \\
\hline IT-intensity & $0.009 * *$ & 0.002 \\
\hline Previous skill obsolescence & $0.421 *$ & 0.171 \\
\hline \multicolumn{3}{|c|}{ Occupational level (reference, intermediate level) } \\
\hline Low level & $-1.302 * *$ & 0.113 \\
\hline High level & $0.344^{* *}$ & 0.101 \\
\hline \multicolumn{3}{|l|}{ Cohort (reference, 1996) } \\
\hline 1994 & $0.308 * *$ & 0.073 \\
\hline 1998 & $0.192 *$ & 0.081 \\
\hline Age & 0.013 & 0.008 \\
\hline \multicolumn{3}{|c|}{ Firm size (reference, category 10-99 employees) } \\
\hline$<10$ employees & -0.222 & 0.139 \\
\hline$\geq 100$ employees & $0.297 * *$ & 0.090 \\
\hline \multicolumn{3}{|c|}{ Economic sector (reference, manufacturing and mining) } \\
\hline $\begin{array}{l}\text { Agriculture, forestry } \\
\text { and fisheries }\end{array}$ & 0.068 & 0.349 \\
\hline Business services & $-0.425^{* *}$ & 0.120 \\
\hline Public services & $-0.947 * *$ & 0.114 \\
\hline
\end{tabular}

Notes: $N=3.131$; Adjusted $R^{2}=0.180$.

$* p<0.05, * * p<0.01$.

Table 5. Regression analysis of training participation

\begin{tabular}{lcc}
\hline & $B$ & Robust SE \\
\hline Constant & $-2.316^{* *}$ & 0.482 \\
IT-intensity & 0.003 & 0.002 \\
Previous skill obsolescence & $0.601^{* *}$ & 0.233 \\
On-the-job learning & $0.139^{* *}$ & 0.020 \\
Tenure & 0.022 & 0.015 \\
Tenure-squared/100 & -0.080 & 0.042 \\
Occupational level (reference, intermediate level) \\
Low level & $-0.276^{*}$ & 0.123 \\
High level & -0.065 & 0.126 \\
Cohort (reference, 1996) & \multicolumn{3}{c}{} \\
1994 & $-0.320^{* *}$ & 0.081 \\
1998 & -0.063 & 0.064 \\
Age & $-0.036^{* *}$ & 0.009 \\
Firm size (reference, category & $10-99$ employees) \\
$\quad<10$ employees & $-0.432^{* *}$ & 0.124 \\
$\geq 100$ employees & 0.045 & 0.112 \\
Economic sector (reference, & manufacturing and mining) \\
Agriculture, forestry & $-0.552^{* *}$ & 0.212 \\
and fisheries & \multicolumn{3}{c}{} \\
Business services & -0.169 & 0.134 \\
Public services & 0.200 & 0.138 \\
\hline
\end{tabular}

Notes: $N=3.235$; Adjusted $R^{2}=0.060$.

$* p<0.05, * * p<0.01$.

In addition, the model predicts that the on-the-job learning will have a positive effect on training participation.

The estimation results presented in Table 5 show that the prediction that a higher IT-intensity leads to greater levels of training participation is not confirmed by the analysis. Workers in IT-intensive jobs are not more likely to invest in formal training than other workers. However, the estimation results confirm the expectation that workers' training participation is positively influenced by prior skill obsolescence, as well as the opportunities for onthe-job learning. The latter finding reinforces the view that learning requirements and opportunities are a structural characteristic of certain jobs. Even in the case of older workers we analyse, the tendency to invest in training is strongly related to on-the-job learning.

Although the effects of tenure and tenure squared are not statistically significant, the direction and size of the coefficients are consistent with the earlier results for probability of job loss as shown in Table 3. The latter show that workers become more secure in their jobs when they achieve more tenure. However, in time the effect of tenure on the probability of job loss becomes smaller, eventually leading to a higher risk of job loss. The coefficients in Table 5 suggest that participation in training may undergo a similar trend and reversal. In this case, the reversal takes place after 14 years, compared to 18 in the case of job loss. Although we must be cautious about interpreting nonsignificant results, this may indicate that when workers with long tenures decrease their efforts to keep their skills up-to-date, this is an early indicator of job loss due to a concentration of experience.

\section{Conclusions}

In this article, we developed a static as well as a dynamic model to explain the relationships between technological change, skill obsolescence, training and informal learning on the job and labour market exit. The static model treats learning processes as exogenous, and assumes a basically sequential causal chain, whereby technological innovations give rise to skill obsolescence that, in the absence of compensatory learning, leads to an increased risk of early exit from the labour market. By contrast, the dynamic model treats learning processes as endogenous to organizations that face a need to develop and change. In this model, skill obsolescence is largely structural by nature. That is to say, changes in skill requirements and the learning of new skills keep each other roughly in balance. As a consequence, this model does not predict an effect of skill obsolescence on the probability of early labour market exit. 
The results of our empirical analyses provide virtually no support for the static model. The only result that was consistent with this model - that previous skill obsolescence is positively related to current skill obsolescence - is also predicted by the dynamic model. The other predictions of the static model are not borne out by the analyses. Workers in IT-intensive jobs are not more likely to perceive skill obsolescence than workers in less IT-intensive jobs. Nor does training participation reduce perceived obsolescence. Finally, and most tellingly, workers' skill obsolescence has no significant effect on the risk of loss of employment in the following period.

We found more evidence supporting the dynamic model. The above-mentioned absence of an effect of skill obsolescence on the chance of losing employment is consistent with this model. Whereas the static model views previous obsolescence as a burden that has to be overcome above and beyond the additional obsolescence induced by technological change, the dynamic model implies that skill obsolescence may be a more or less structural characteristic of many jobs. Moreover, training participation was found to have a significant negative effect on the probability of losing employment. However, contrary to the predictions of the static model, training participation does not reduce perceived skill obsolescence. This is consistent with the idea, incorporated in the dynamic model, that the training that is related to technological innovations represents an important investment in human capital, which employers and employees have an interest in recouping through a longer employment duration (cf. Bartel and Sicherman, 1993). A similar result is observed for job tenure. Initially, longer job tenure has a negative effect on the chances of loss of employment, indicating that workers accumulate valuable additional human capital through work experience. This effect decreases over time, however, and after about 18 years additional tenure actually increases the probability of employment loss, indicating that the experience build-up no longer dominates the depreciation of the worker's skills.

On-the-job learning is found to be related with perceived skill obsolescence, which supports the dynamic model. Moreover, those employed in IT-intensive jobs are more likely to learn on the job. Furthermore, on-the-job learning has a positive influence on training participation. These results are consistent with the idea that skill obsolescence, and investments in training as well as on-the-job learning are all more or less structural characteristics of jobs that are highly challenging and dynamic. In this view, the skill obsolescence that workers in these jobs perceive may remain relatively constant: as new skills are acquired to fill a prior skill gap, and new requirements are thrown up, which necessitates further learning in a subsequent period. Because this is driven by changes that increase the net productive potential of jobs, this does not lead to an increased risk of loss of employment. Instead, by stimulating further investments in the human capital of the workers who are employed in these jobs, it decreases the probability that these workers lose their employment.

\section{References}

Acemoglu, D. (1997) Training and innovation in an imperfect labour market, Review of Economic Studies, 64, 445-64.

Bartel, A. P. and Sicherman, N. (1993) Technological change and retirement decisions of older workers, Journal of Labor Economics, 11, 162-83.

de Grip, A. and van Loo, J. (2002) The economics of skills obsolescence: a review, Research in Labor Economics, 21, 1-26.

Dickerson, A. and Green, F. (2004) The growth and valuation of computing and other generic skills, Oxford Economic Papers, 56, 371-406.

Dorn, D. and Sousa-Poza, A. (2008) 'Voluntary' and 'involuntary' early retirement: an international analysis, Applied Economics, 42, 427-38.

Eraut, M. (2000) Non-formal learning and tacit knowledge in professional work, British Journal of Educational Psychology, 70, 113-36.

Jorgenson, D. W. (2001) Information technology and the US economy, American Economic Review, 91, 1-32.

Jovanovic, B. (1979) Job matching and the theory of turnover, Journal of Political Economy, 87, 972-90.

Machin, S. and van Reenen, J. (1998) Technology and changes in skill structure: evidence from seven OECD countries, Quarterly Journal of Economics, 113, $1215-44$.

Maurin, E. and Postel-Vinay, F. (2005) The European job security gap, Work and Occupations, 32, 229-52.

OECD (2001) Economics and Finance of Lifelong Learning, OECD, Paris.

Rosen, S. (1972) Learning and experience in the labor market, Journal of Human Resources, 7, 326-42.

Sieben, I., de Grip, A., Longen, J. and Sørensen, O. (2009) Technology selection, and training in call centers, Industrial and Labor Relations Review, 62, 553-72.

van Loo, J., de Grip, A. and de Steur, M. (2001) Skills obsolescence, causes and cures, International Journal of Manpower, 22, 121-37.

van Smoorenburg, M. S. M. and van der Velden, R. K. W. (2000) The training of school-leavers: complementarity or substitution?, Economics of Education Review, 19, 207-17.

Weiss, M. and Garloff, A. (2009) Skill-biased technological change and endogenous benefits: the dynamics of unemployment and wage inequality, Applied Economics, 43, 811-21.

Welch, F. and Ureta, M. (2002) The obsolescence of skill, Research in Labor Economics, 21, 51-81. 